DOI: $10.4274 /$ tftr.56.67

\title{
Comparison of Continuous and Intermittent Filling Cystometry in Patients with Spinal Cord Injury
}

\section{Spinal Kord Yaralanmalı Hastalarda Sürekli ve Aralıkı Dolum Sistometrisinin Karșılaștırılması}

\author{
Kurtuluş KAYA, Murat ERSÖZ* , Engin KOYUNCU**, Sumru ÖZEL***, Müfit AKYÜZ****, Neşe ÖZGiRGiN** \\ Tatvan Devlet Hastanesi, Bitlis, Turkey \\ *Ankara Fizik Tedavi ve Rehabilitasyon Eğitim ve Araştırma Hastanesi, 6. FTR Kliniği, Ankara, Türkiye \\ **Ankara Fizik Tedavi ve Rehabilitasyon Eğitim ve Araştırma Hastanesi, 5. FTR Kliniği, Ankara, Türkiye \\ **Ankara Fizik Tedavi ve Rehabilitasyon Eğitim ve Araştırma Hastanesi, 3. FTR Kliniği, Ankara, Türkiye \\ ***Ankara Fizik Tedavi ve Rehabilitasyon Eğitim ve Araştırma Hastanesi, 1. FTR Kliniği, Ankara, Türkiye
}

\section{Summary}

Objective: Continuous medium filling cystometry at a rate of $50 \mathrm{ml} / \mathrm{min}$ is a widely used method due to its advantages such as short filling time and published reference values. However, this type of filling sometimes provokes detrusor contractions and may cause incorrect bladder capacity determinations. The aim of this study was to compare the continuous and intermittent filling during cystometry in patients with spinal cord injury ( $\mathrm{SCl}$ ) who had detrusor overactivity.

Materials and Methods: Twenty patients with $\mathrm{SCl}$ who had detrusor overactivity were included in the study. After the drainage of all urine, first, the bladder was filled continuously at a filling rate of $50 \mathrm{ml} / \mathrm{min}$ with sterile physiological saline at room temperature and the maximum cystometric capacity was determined. After the continuous filling cystometry, the bladder was emptied again and filled intermittently by 30 seconds filling followed by 15 seconds pause periods at filling rate of $50 \mathrm{ml} / \mathrm{min}$. The maximum cystometric capacities observed during continuous and intermittent filling were compared by the Wilcoxon signed rank test.

Results: The mean maximum cystometric capacities were $86.5 \pm 43.7 \mathrm{~m}$ and $122.7 \pm 62.2 \mathrm{ml}$, respectively in continuous and intermittent filling ( $p<0.001)$. The mean increase in intermittent filling was $36.2 \pm 38.1 \mathrm{ml}$ which represented a $41.84 \%$ mean increase.

Conclusion: In this study, higher cystometric capacities were observed in $\mathrm{SCl}$ patients with overactive detrusors by intermittent filling. This method may serve determination of bladder capacity more correctly and may contribute to make appropriate therapeutic decisions in patients with detrusor overactivity. Turk J Phys Med Rehab 2010;56:67-70. Key Words: Intermittent filling, cystometry, spinal cord injury, overactive urinary bladder
Özet

Amaç: Elli ml/dk hızda yapılan orta hızlı sürekli dolum sistometrisi dolum süresinin kısalı̆̆ı ve yayınlanmış referans değerlerinin oluşu gibi avantajları nedeniyle yaygın olarak kullanılan bir metotdur. Bununla birlikte bu tip dolum bazen detrüsör kontraksiyonlarını provoke edebilir ve mesane kapasitesini saptamada hatalara neden olabilir. Bu çalışmanın amacı aşırı aktif detrüsöre sahip omurilik yaralanmalı (OY) hastalarda sürekli ve aralıklı dolumla yapılan sistometrik ölçümlerin karşılaştırılmasıdır.

Gereç ve Yöntem: Çalışmaya aşırı aktif detrüsöre sahip OY'li 20 hasta dahil edildi. Mesanedeki tüm idrar boşaltıldıktan sonra, mesane ilk önce oda sıcaklığındaki steril serum fizyolojik ile $50 \mathrm{ml} / \mathrm{dk}$ hızla sürekli olarak dolduruldu ve mesane kapasitesi belirlendi. Sürekli dolum sistometrisinden sonra mesane tekrar boşaltıldı ve $50 \mathrm{ml} / \mathrm{dk}$ dolum hızıyla 30 saniyelik dolum periyodlarını izleyen 15 saniyelik duraklamalarla aralıklı olarak dolduruldu. Sürekli ve aralıklı dolum sırasında saptanan kapasiteler Wilcoxon işaretli sıra testi ile karşılaştırıldı.

Bulgular: Maksimum sistometrik kapasite ortalama değerleri sürekli ve aralıklı dolumda sırasıyla $86,5 \pm 43,7 \mathrm{ml}$ ve $122,7 \pm 62,2 \mathrm{ml}$ idi $(p<0,001)$. Aralıklı dolumla saptanan ortalama artış $36,2 \pm 38,1 \mathrm{ml}$ idi ve bu ortalama \%41,84'lük bir artışa tekabül ediyordu.

Sonuç: Bu çalışmada aşırı aktif detrüsörlü OY'li hastalarda aralıklı dolum ile daha yüksek sistometrik kapasiteler gözlendi. Bu yöntem aşırı aktif detrüsörlü hastalarda mesane kapasitesinin daha doğru belirlenmesine ve uygun tedavi kararlarının verilmesine yardımcı olabilir. Türk Fiz Tıp Rehab Derg 2010;56:67-70.

Anahtar Kelimeler: Aralıklı dolum, sistometri, spinal kord yaralanması, aşırı aktif mesane 


\section{Introduction}

For many years, conventional artificial filling cystometry (CMG) has been the standard method of investigating lower urinary tract function (1). Today, most urodynamic investigations are conventional urodynamic investigations with standardized techniques following the recommendations of the International Continence Society (2). These studies provided useful data on the dynamic events occurring during bladder filling, storage and micturition. However, the artificial nature of CMG may impose constrains on the reliability of the data $(1,3)$. CMG with continuous filling is different from natural filling, which occurs intermittently from the ureters and has a variable rate within one collecting phase. Natural filling allows the bladder to accommodate, while CMG creates an artificial condition with continuous pressure rise (4). However, the natural filling method of cystometry can be labor-intensive and time-consuming (1).

High intravesical pressure and low compliance during bladder filling are common findings during CMG, even with relatively slow artificial filling rates in patients with neurogenic bladder dysfunction. The higher artificial filling rates are associated with lower bladder compliance and higher pressure rises during filling in patients with neurogenic bladder $(5,6)$. Significant decrease in maximum detrusor pressure and increase in bladder compliance had been demonstrated in $\mathrm{SCl}$ patients with detrusor overactivity by furosemide-stimulated filling cystometry (FCMG), which is a more physiologic method when compared with continuous CMG with a filling rate of $50 \mathrm{ml} / \mathrm{min}$ (1). However, no significant difference was observed in patients with hypo-areflexic detrusors in the same study (1). These results have shown the need for development of more physiologic bladder filling methods in patients with detrusor overactivity.

In the vast majority of clinical urodynamic studies, $50 \mathrm{ml} / \mathrm{min}$ has been the preferred filling rate $(7,9)$. However, this type of filling sometimes provokes detrusor contractions and may cause incorrect bladder capacity determinations. As urine drainage depends on bladder changes (increases, decreases or even stops) in normal physiological conditions according to the level of hydration, we hypothesized that intermittent filling may be more physiological than continuous filling during cystometry. In the literature, we did not find any study on intermittent filling cystometry in patients with detrusor overactivity.

The aim of this study was to compare continuous and intermittent filling cystometry with a filling rate of $50 \mathrm{ml} / \mathrm{min}$ in patients with spinal cord injury who had detrusor overactivity.

\section{Materials and Methods}

A total of 20 patients (17 male, 3 female) with $\mathrm{SCl}$ and overactive detrusors and who had terminal detrusor contractions before the infused volume reached $200 \mathrm{ml}$ during cystometric evaluation were included in the study. Terminal detrusor overactivity is defined as a single, involuntary detrusor contraction occurring at cystometric capacity, which cannot be suppressed and results in incontinence usually resulting in bladder emptying (2). The patients with reduced bladder compliance, but without detrusor overactivity were excluded. Twelve of the
20 patients were not using anticholinergic drugs, while 8 of them were on anticholinergic drug therapy at the time of cystometric examinations. Informed consent was obtained from all patients and the study protocol was approved by the local ethics committee of our institution.

\section{Procedure}

Age, type of injury, neurological level and the American Spinal Injury Association (ASIA) classification of each patient were recorded. Urodynamic examinations were performed by Libra $^{+}$(MMS, Enschede, The Netherlands) urodynamic measurement system, using a double lumen $8 \mathrm{~F}$ sterile urethral catheters. After the drainage of all urine, first, the the bladder was filled continuously at a filling rate of $50 \mathrm{ml} / \mathrm{min}$ with sterile physiologic saline at room temperature and the maximum cystometric capacity was determined. After the continuous filling cystometry, bladder was emptied again and 5 minutes later was filled intermittently by 30 seconds filling followed by 15 seconds pause periods at filling rate of $50 \mathrm{ml} / \mathrm{min}$. The maximum cystometric capacities and filling times observed during continuous and intermittent filling were determined. The patients who had capacities of $200 \mathrm{ml}$ or more were determined as candidates for intermittent catheterization (8). The number of patients who could be shifted to intermittent catheterization in two filling methods were noted. We also calculated the time needed for reaching the bladder capacity observed in intermittent filling with a filling rate of $15 \mathrm{ml} / \mathrm{min}$, which is the upper limit of physiological filling rate in an individual with a body weight of $60 \mathrm{~kg}(4)$.

\section{Statistical Analysis}

The SPSS software Version 9.0 (Chicago USA) was used for data analysis and values of $p<0.05$ were considered statistically significant. Descriptive statistics were performed. The maximum cystometric capacities and the filling times observed during continuous and intermittent filling were compared by the Wilcoxon signed rank test. We also compared the filling times observed in intermittent filling and the calculated time needed for reaching the bladder capacity observed in intermittent filling with a filling rate of $15 \mathrm{ml} / \mathrm{min}$ by the Wilcoxon signed rank test.

\section{Results}

Demographic and clinical features of the patients in the study were given in Table 1. There was a statistically significant difference between the mean maximum cystometric capacities in continuous filling $(86.5 \pm 43.7 \mathrm{ml}$, min:24-max:173 ml) and in intermittent (122.7 $\pm 62.2 \mathrm{ml}$, min:28-max:290 ml) filling, ( $p<0.001$, Table 2, Figure 1). The mean increase in maximum cystometric capacity in intermittent filling was $36.2 \pm 38.1 \mathrm{ml}$, which represented a $41.8 \%$ mean increase (Table 2 ). Higher maximum cystometric capacities were observed by intermittent filling in 19 of 20 patients (95\%). According to the results of the continuous filling test, none of the patients had enough capacity for intermittent catheterization. However, the increases in bladder capacities observed by intermittent filling gave the opportunity to shift to intermittent catheterization from indwelling catheterization in three patients.

The time spent during intermittent filling (211.1 \pm 110.2 seconds, min:35-max:485 seconds) was significantly longer 
than the time spent during continuous filling (91.4 \pm 47.1 seconds, min:30-max:214 seconds) ( $p<0.001)$. However, the time spent during intermittent filling (211.1 \pm 110.2 seconds) was significantly shorter than the time needed for reaching the same capacity with continuous filling with a rate of $15 \mathrm{ml} / \mathrm{min}$. (490.6 \pm 248.8 seconds) ( $p<0.001)$.

\section{Discussion}

The filling rate of $50 \mathrm{ml} / \mathrm{min}$ is the upper limit of medium filling cystometry (4). However, continuous medium fill cystometry at a rate of $50 \mathrm{ml} / \mathrm{min}$ sometimes provokes detrusor contractions (9) and may cause incorrect bladder capacity determinations in the presence of detrusor overactivity. As bladder management is very important for preservation of urinary system function in patients with $\mathrm{SCl}$ and bladder emptying method has a great impact on quality of life of them and bladder emptying method had been shown to be a significant factor in returning back to work (10), making the correct evaluation and the appropriate therapeutic decision is very important in this patient group. On the other hand, filling cystometry at physiological filling rates take much time and only limited number of patients can be tested in a determined time period. As a possible solution, we filled the bladder intermittently by 30 seconds filling followed by 15 -second pause periods at filling rate of $50 \mathrm{ml} / \mathrm{min}$ and observed significantly higher capacities (mean increase 41.8\%) with acceptable increase in filling time (nearly two fold) in comparison to continuous filling cystometry. The filling time prolongation is due to pause periods in part, but an important portion of the increase was due to increased maximum cystometric capacity, which could be achieved by delayed detrusor contraction as a result of pause periods. Although the time spent during intermittent filling increased, it was still two fold shorter than the time needed for reaching the same capacity with continuous filling with a rate of $15 \mathrm{ml} / \mathrm{min}$, which is the upper limit of physiologic filling. By intermittent filling, higher maximum cystometric capacities were observed in 19 of 20 patients $(95 \%)$ regardless of whether the patient was on anticholinergic therapy or not at the time of the investigation and these increases gave the opportunity to shift to intermittent catheterization from indwelling catheterization in three patients.

In a previous study, Andersson et al. (11) conducted continuous cystometry and stepwise cystometry consecutively in healthy individuals. In stepwise cystometry, first the bladder was filled to approximately half of the maximal volume and allowed to relax for $5 \mathrm{~min}$, then stepwise cystometry was performed. By this method, higher bladder capacity and lower transmural pressure were observed. This finding shows the importance of pause periods during bladder filling even in healthy individuals. In our study, we performed two cystometric evaluations with an interval of five minutes between them. In a previous study, intervals of 10 minutes were reported (12). We

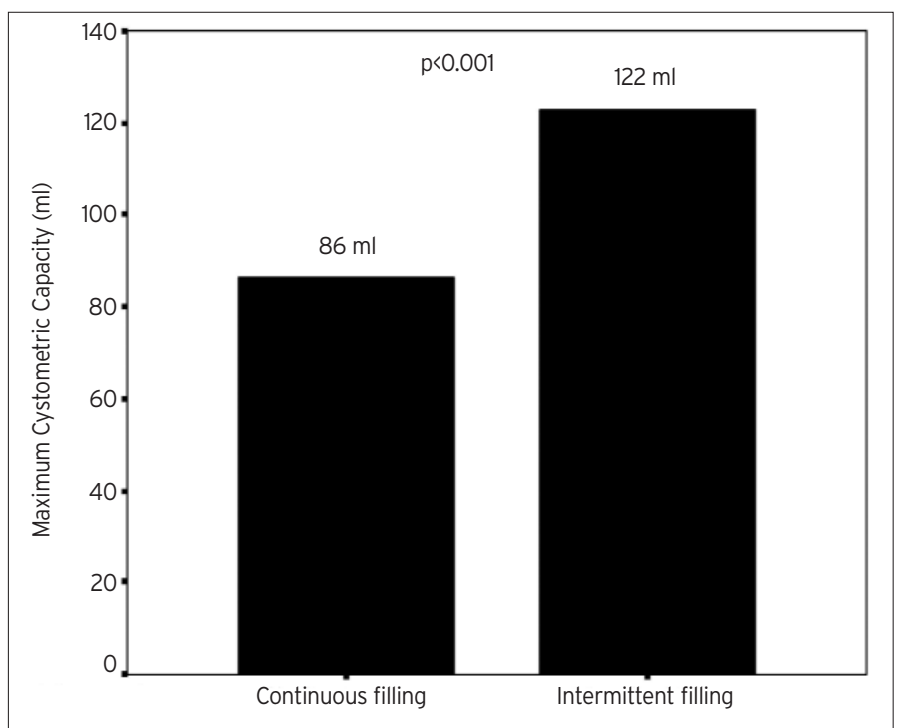

Figure 1. Maximum cystometric capacities observed during continuous and intermittent filling.

Table 1. Demographic and clinical features of the patients in the study.

\begin{tabular}{|l|c|}
\hline Mean age (years) & $33.2 \pm 12.5$ \\
\hline Mean interval between the injury and the urodynamic investigation (months) & $30.7 \pm 30.3$ \\
\hline Gender (female/male) & $3 / 17$ \\
\hline Level of lesion (cervical/thoracal/lumbosacral) & $5 / 14 / 1$ \\
\hline ASIA class (A/B/C/D) & $14 / 2 / 3 / 1$ \\
\hline Etiologic factors (vehicle accident/fall/gun shot/diving & $7 / 7 / 5 / 1$ \\
\hline
\end{tabular}

Table 2. Comparison of maximum cystometric capacities observed and time spent during continuous and intermittent filling cystometries in SCI patients with overactive detrusors.

\begin{tabular}{|c|c|c|c|}
\hline & Continuous filling & Intermittent filling & $P$ \\
\hline Maximum cystometric capacity (ml) & $\begin{array}{c}86.5 \pm 43.7 \\
\text { median=90 (24-173) }\end{array}$ & $\begin{array}{c}122.7 \pm 62.2 \\
\text { median=117.5 }(28-290)\end{array}$ & $<0.001$ \\
\hline Mean increase in maximum cystometric capacity $(\mathrm{ml})$ & & $36.2 \pm 38.1$ & \\
\hline Mean increase in maximum cystometric capacity (\%) & & 41.8 & \\
\hline Time spent during filling (seconds) & $\begin{array}{c}91.4 \pm 47.1 \\
\text { median=90.5 (30-214) }\end{array}$ & $\begin{array}{c}211.1 \pm 110.2 \\
\text { median=199 (35-485) }\end{array}$ & $<0.001$ \\
\hline
\end{tabular}


preferred a shorter interval for shortening the total duration of the examination and lowering the risk of pressure ulcer development in our patients. In our study, we did not perform the continuous and intermittent filling cystometries in a random fashion, which can be mentioned as a limitation of our study. However, we do not think that repeated cystometries had a major effect on the increased capacity in the intermittent filling cystometry as Thyberg et al. (12) found no significant difference between the mean maximum detrusor pressure in the first and second cystometries compared with the third and fourth cystometries, which were performed with 10 minutes intervals between them in a $\mathrm{SCl}$ population with overactive detrusors. Similarly, Ockrim et al. performed 3 sequential cystometries in men with $\mathrm{SCl}$ and reported that cystometric variables and detrusor overactivity remained consistent over sequential studies (13).

Although not performing a third cystometric study with a filling rate of $15 \mathrm{ml} / \mathrm{min}$ for comparison with continuous and intermittent cystometric studies with filling rate of $50 \mathrm{ml} / \mathrm{min}$ appeared as a limitation of our study, we think that our results are important as they demonstrated advantages of intermittent filling in patients with overactive detrusors. However, new studies investigating various filling-pause cycles with changing pause and filling durations at different filling rates will better reveal the best method. Another point to mention here is the difficulty in starting and stopping the pump manually in every 30-15 seconds. We feel that adding intermittent filling cycles in software of urodynamic measurement systems will solve this problem.

\section{Conclusion}

We conclude that higher cystometric capacities can be achieved in $\mathrm{SCl}$ patients with overactive detrusors by intermittent filling. This method may serve determination of bladder capacity more correctly and may contribute to make appropriate therapeutic decisions. However, new studies with larger sample sizes investigating various filling-pause cycles with changing pause and filling durations are needed.

\section{References}

1. Ko HY, Lee JZ, Park HJ, Kim H, Park JH. Comparison between conventional cystometry and stimulated filling cystometry by diuretics in a neurogenic bladder after spinal cord ınjury. Am J Phys Med Rehabil 2002;81:731-5. [Abstract]

2. Abrams P, Cardozo L, Fall M, Griffiths D, Rosier P, Ulmsten U, et al. The standardisation of terminology in lower urinary tract function: report from the standardisation sub-committee of the International Continence Society. Urology 2003;61:37-49. [Abstract] / [Full Text] / [PDF]

3. Robertson AS. Behaviour of the human bladder during natural filling: the newcastle experience of ambulatory monitoring and conventional artificial filling cystometry. Scan J Urol Nephrol 1999;201:19-24. [Abstract] / [PDF]

4. Klevmark B. Natural pressure-volume curves and conventional cystometry. Scand J Urol Nephrol Suppl 1999;20:1-4. [Abstract]

5. Webb RJ, Styles RA, Griffiths CJ, Ramsden PD, Neal DE. Ambulatory monitoring of bladder pressures in patients with low compliance as a results of neurogenic bladder dysfunction. $\mathrm{Br} J$ Urol 1989;64:150-4. [Abstract]

6. Webb RJ, Griffiths CJ, Ramsden PD, Neal DE. Ambulatory monitoring of bladder pressure in low compliance neurogenic bladder dysfunction. J Urol 1992;148:1477-81. [Abstract]

7. Klevmark B. Volume threshould for micturition. influence of filling rate on sensory and motor bladder function. Scan J Urol Nephrol Suppl 2002;210:6-10. [Abstract] / [PDF]

8. Consortium for Spinal Cord Medicine. Bladder Management for Adults with Spinal Cord Injury: A Clinical Practice Guideline for Health-Care Providers. Spinal Cord Medicine. Paralyzed Veterans of America, ISBN-0-929819-19-5, August 2006. p. 1-61.

9. Ersoz M, Akyuz M. Bladder-filling sensation in patients with spinal cord injury and the potential for sensation dependent bladder emptying. Spinal Cord 2004;42:110-6. [Full Text] / [PDF]

10. Kurtaran A, Akbal A, Ersöz $M$, Selçuk B, Yalçın E, Akyüz $M$. Occupation in spinal cord injury patients in Turkey. Spinal Cord 2009;47:709-12. [Abstract] / [Full Text] / [PDF]

11. Andersson S, Bjerle P, Hentschel J, Kronström A, Niklasson U. Continuous and stepwise cystometry though suprapubic catheters-effect of infusion pattern and infusion rate on the cystometrogram of the normal human bladder. Clin Physiol 1989;9:89-96. [Abstract]

12. Thyberg $M$, Spangberg $A$, Lassvik $C$. Detrusor pressure in cystometry compared to physiological filling in patients with a reflex urinary bladder after spinal cord injury. Scan J Rehab Med 1990;22:145-50. [Abstract]

13. Ockrim J, Laniado ME, Khoubehi $B$, Renzetti $R$, Finazzi Agrò $E$, Carter SS, et al. Variability of detrusor overactivity on repeated filling cystometry in men with urge symptoms: Comparison with spinal cord injury patients. BJU Int 2005;95:587-90. [Abstract] / [Full Text] / [PDF] 